\title{
Feasibility Study of the Integration of Professional English and Basic English in Vocational Colleges
}

\author{
Shuning Liu
}

Guang'an Vocational and Technical College, China

Keywords: Professional English, Basic English, Integration, Feasibility.

\begin{abstract}
In recent years, the quality and practice of our higher vocational education have achieved progress in certain degree. But deep-rooted traditional education mode still imposes strong traditional education color on both theory and practice of higher vocational education. Nowadays, higher vocational colleges don't pay enough attention to professional English teaching in general, resulting in poor effect with formalism in most parts. On the basis of features of higher vocational education, this article discusses how to permeate professional English to Basic English teaching to achieve effective integration, and studies its feasibility.
\end{abstract}

\section{Introduction}

Professional English education has widely set in higher vocational colleges, but the implementation is not good enough, for related arrangements, such as teachers, teaching materials, teaching methods and task setting, are much casual and lack systematic plans. Thus, the professional English course has become no more than a form in most places, and professional English still doesn't gain as much attention as Basic English. Practicability is the key of higher vocational education. However, today's professional English teaching merely asks students to recite several professional English words or read some technological articles to achieve practicability, rather than doing it from the point of occupational positions. Even many graduations can neither understand professional English materials and papers in work nor talk with professionals in English. This leads to a timeconsuming and low-effective condition of English teaching in higher vocational colleges.

As a kind of education cultivating applied talents, English teaching in higher vocational education should establish career goals, improve training in professional English skills and stress the application of language. It should be urgent affairs to effectively combine Basic English and professional English as well as English learning and professional learning in order to achieve progress both in expertise competence and applied ability of professional English, because it has significant meaning to the development of higher vocational teaching.

\section{The Status Quo of Higher Vocational English Teaching}

\subsection{Unreasonable setup of teaching content}

Nowadays, most of the higher vocational colleges set the professional English courses after a semester of Basic English teaching. But a majority of high school graduates' English level is close to the requirements and standards of fundamental stage of college English teaching, which almost becomes a repetition of junior and senior high school English courses. According to my survey, a lot of students complain that they learn too little in college English classes and perform worse in English than their high school performance on the contrary because of the disappearance of pressure in college entrance examination. The lagging of English for special purpose education combining with the redundancy of Basic English teaching make this segmented teaching arrangement lose its ideal effect.

\section{2 lacking of attention}

Although professional English has been widespread in higher vocational colleges, the arrangement of teachers, implementation of teaching and the choosing of textbook are still casual. Colleges conduct no market survey and lack analysis of tasks and choosing of professional language data so that practical guidance is absent in teachers' teaching practice. And some even know nothing about 
students' real competence, resulting in "up to $79 \%$ of students consider existing textbook is too difficult while $73 \%$ think the content is boring"(Zhuang Weiwei, 2011).

\section{The Necessity of effective integration of professional English and basic one}

\subsection{From the Standpoint of "Input Hypothesis" and "the Zone of Proximal Development"}

When expounding the relationship between education and development, Vygotsky comes up with an important concept, the Zone of Proximal Development, which is the zone between present level and potential development level of a learner. The ideal teaching effect is made in the Zone of Proximal Development. So in order to promote learners to obtain knowledge and skills more effectively, teaching activities should constantly turn students' Zone of Proximal Development into present actual level. If input language data is so difficult that it surpasses learners' level, it will have negative effect to learners' development of acknowledging level no matter how much it was input. It is the same that too easy data input also does harm to learners' language improvement. Though students in higher vocational colleges has poor English basis, they have obtained a certain degree of grammar and words after studying English for more than ten years. So neither repeating Basic English practice nor entering into professional English learning without considering their present English degree is possible. It will make them lose interest in English or cannot tackle with expertise English materials in high difficulty. Therefore, the segmented teaching mode in higher vocational colleges, which divides Basic English education from professional English study, is unsuitable for their students.

Considering the four necessary characteristics of language input put forward by Krashen, that is comprehension, interesting and relevant, non-grammatical sequenced and enough input (i+1), English teachers in higher vocational colleges should hold the distance between language input and learners' English level and take the correlation between learning content and learners' future occupation into consideration. Thus, English in higher vocational colleges should not be total repetition of merely basic language skill learning, nor using professional English courses to replace basic one. It should consider several objective sectors such as students' English degree, study interest, features of their subject as well as requirements of company and gradual penetrate professional English into education of the basic one to improve connection between them and lay foundation for future professional English learning.

A mode of English teaching reform like this is a huge challenge for English teachers. However, it can strengthen English basis of students', cultivate students' ability of professional English, stimulate learning interest of students', improve effects of classroom teaching, and help students build a solid foundation for their transition to study of higher level professional English and even learning professional English automatically. The purpose is to achieve the cultivative target of vocational college English teaching, "take vocational development as the guidance", so as to satisfy needs of the society.

\subsection{From the Perspective of "Demand Analysis" Theory}

Demand analysis means to learn about the needs of language learners on language learning and arrange study process according to the importance of the needs. Hutchinson and Waters (1987) divided needs into "learning demand" and "target demand". Learning demand deals with what learners should do in order to realize their communicative language ability under target situations. Target demand refers to language skills learners need to have while implementing communicative activities in target situations. The key point of analysis demand lies in the research process to find out the gap between learners' present level and skill required under target situations, so as to discover and analyze the education and teaching problem.

Professional English teaching starts from demand analysis focuses on analysis and satisfying different needs of different learners, instead of teaching with certain methods of subjective judgment. Basic English teaching in higher vocational colleges neglects current English level of students who have just attended college entrance examinations. The repeating basic practice makes students lose their interest in English learning. Target demand of professional English teaching period lacks detail but indistinct. Students do not know how to utilize professional English vocabulary they've learned in working scenarios. Professional English teaching in higher vocational colleges should be an 
English course open for cultivating students to utilize English for work in certain working scenarios according to their learning ability and purposes. The English course mode suits higher vocational colleges most should be the one that penetrates and integrates professional English and basic English as a whole to make them play their own roles and let professional English run through students' English learning. Making comprehensive and detailed current situation and target situation analysis on employment posts, specific working tasks, and language ability requirements should be finished before courses designing in order to extract ability of English utilization that adapts to the occupational area and make the detail into formulation of courses and teaching target. Secondly, selecting teaching contents that real target situation needs and designing tasks of teaching and learning according to students' current level, satisfying students' demands on basic learning, learning purpose, and learning interest, etc. to the utmost extent is necessary.

\section{Empirical Research on Effectively Integrating Professional English and Basic English}

With empirical teaching of penetrating professional English learning into basic English teaching, the author verifies whether the effective integrated teaching mode can not only improve students' basic English level, but also help students gain utilizing ability of professional English and whether it can produce positive effects on improving students learning interest and autonomy.

\subsection{Object of Study}

The author did teaching experimental unit research with freshmen in two class extracted respectively from architectural engineering technology profession and project fabrication cost profession, architecture and urban planning department, grade 2014 of the college that the author studies in, in which the class of architectural engineering technology profession is the experimental class with 47 students, and the class of project fabrication cost profession is the control class with 45 students. Results of the English level tests that we asked students from the above classes to take in the first week of school showed no obvious difference between two classes' English level before the experiment (table 1).

Table 1. Results of the English level tests

\begin{tabular}{|c|c|c|}
\hline Class Type & Experimental class & Control class \\
\hline Average score & 70.15 & 70.89 \\
\hline
\end{tabular}

\subsection{Designing and Process of Research}

Comprehensive English courses taught by designated teachers of English were planned for the first and second semesters of the control class (of project fabrication cost profession), and professional English courses taught by project fabrication cost designated teachers with masters' degrees and CET6 for the third and fourth semesters. Teaching reform of the experimental class (of architectural engineering technology profession) started with its entry point - course design, which were taught all by designated teachers of English and with related architectural engineering technology experts, architectural engineering technology professional teachers, and designated teachers of English discussing concrete content of courses together. For the first semester, communicative ability training took the main position of teaching, with students' daily life and study related situational dialogue selected, penetrating professional English teaching gradually into basic English teaching. For the second and third semesters, took working scenarios as background, we carried out basic and application simultaneously with English application ability improvement and professional English and basic English integration. For the fourth semester, authentic materials in working scenarios were adapted as content of courses, and professional teaching were through the whole basic English learning process.

Main penetrating and integrating teaching forms taken in teaching process include: (1) methods of morphology, one-cored lexical polysemy word clustering, etc. penetrating professional English terms teaching, for example, attach learning meaning and usage in basic English consciously while teaching some professional words and terms. (2) frequent penetration of general daily professional terms, for 
instance, students may be aroused keen interest when talk about contents related closely to our life such as house, decorations, etc. therefore we can guide students to learn related words. (3) task-based teaching under working scenarios, e.g. enable students to read some operation instruction manuals of building materials of moderate difficulty and then promote sale of building materials in English simulating building materials vendors.

\subsection{Effect analysis}

After infiltrating professional English in teaching for one year, was the experimental class acting better in mastering professional English basic knowledge and applying basic language ability than the comparing class? Based on Basic Requirements of Vocational College English Teaching and Practical English Test Syllabuses for Colleges, the writer made a separate test on experimental class and comparing class,by using Practical English Test for Colleges as a template to give them a written examination. Those examination includes the translation of professional English phrase, reading comprehension and practical writing of daily use (table 2 ).

Table 2: The final exam result of first \& second semester

\begin{tabular}{|c|c|c|}
\hline $\begin{array}{c}\text { class } \\
\text { score } \\
\text { term }\end{array}$ & $\begin{array}{c}\text { First semester } \\
\text { Final exam result }\end{array}$ & $\begin{array}{c}\text { Second semester } \\
\text { Final exam result }\end{array}$ \\
\cline { 2 - 3 } & Average & Average \\
\hline Comparing class & 71.61 & 72.39 \\
\hline Experimental class & 72.35 & 78.25 \\
\hline
\end{tabular}

Totally, there 3 exams,one of the exams was before the experiment and two after the experiment.The exam result shows that the average score of comparing class is 70.89,71.61 and 72.39 for each time. These score are quite similar, which means traditional Basic English teaching can't greatly improving students' English application ability. For the first semester final exam, the score of comparing class and experimental class are 71.61 and 72.35 , not a big difference. But the gap is widen in the second semester final exam with the score of 72.39 and 78.25. This suggests that the new teaching method has some advantages. Thus it can be seen that, the way to infiltrate professional English in basic English teaching not only has an effect on students' basic English learning, but also solid their fundamental English knowledge, gradually cultivate their application of professional English, to reduce the difficulty of the coming professional English learning, truly improve the actual effect of English teaching.

In order to further understand the students' attitude towards the basic English and professional English teaching, research group conducted a questionnaire survey among 47 students in experimental classes to analyze their learning demand and the satisfaction to teachers, textbooks and so on. From 47 completed questionnaires, we can see 40 students agreed to set up the English courses with the combination of basic English and professional English; Five students selected "professional English courses only, without the need to learn basic English ". Two students chosen "only courses in basic English". It is visible that, most of the students are quite agree with that the teaching method and basic English and professional English should be carried out simultaneously. On the choice of teaching content, $85.3 \%$ of students have the preference to choose " English application ability training under the background of work situation", only $4.1 \%$ of students chosen to "continue to strengthen the training of the basic grammar"; On the teaching material, $91.2 \%$ of students chosen " using real work corpus as a teaching material". This suggests that vocational college students have a strong demand for professional English learning.

In addition,ten students have been interviewed by writer at random, they widely have a great interest in the way of professional English integrated in teaching material which is effective and help them a lot in professional development. Eight of the students said they reviewed and learned by themselves after class. This shows that the new teaching method is beneficial to improvement of students' interest in English learning and is effective for promoting students' autonomous learning ability. 


\section{Conclusion}

The integration of professional English and basic English teaching method helps students consolidate their English foundation to help the students gain professional English application ability and lay a good foundation for their successful transition for a high level of professional English learning. It is reasonable and scientific to combine the teaching method of professional English with basic English, it also conform to the requirement of teaching. During the teaching process of vocational colleges, the characteristic of practicality and professionalism should be remain throughout the whole process, instead of being carried out segmentally . English teachers need to change their teaching concepts, in order to inspire students' interests and motivation in English learning, and truly improve the effect of English class.

\section{Reference:}

[1]. Hutchinson T, Waters A. English for Specific Purposes: a Learning Centered Approach [M]. Cambridge: Cambridge University Press, 1987.

[2]. Krashen S. (1985). The Input Hypothesis: issues and applications [M]. London: Longman,1985.

[3]. Ni Chuanbin. The Research and Analysis of English Teaching Engagement between Secondary School and University Foreign Language and Foreign Language Teaching [J] 1998

[4]. Weiwei Zhuang. The Current Survey and Improvement Suggestion of Vocational College ESP course [D]. Shanghai: East China Normal University, 2011

[5]. Cai Jigang, Liao Leichao Academic English or Professional English Foreign Language Teaching [J] 2010

[6]. Yin Hesu, Yan Qigang Discussion of the Relationship between College English General Education and English Teaching for Specific Purpose Foreign Language Telephone Instruction [J] 2011 